\title{
Isolation and characterization of mesenchymal stem cells derived from bovine Wharton's jelly and their potential for use in cloning by nuclear transfer
}

\author{
Isolamento e caracterização de células tronco mesenquimais derivadas de geléia de Wharton \\ bovina e seu potencial para uso na clonagem por transferência nuclear
}

\author{
Carolina Gonzales da Silva ${ }^{\mathrm{I}, \mathrm{II}}$ Carlos Frederico Martins ${ }^{\mathrm{II}^{*}}$ Tereza Cristina Cardoso $^{\mathrm{III}}$ \\ Elisa Ribeiro da Cunha ${ }^{I}$ Heidi Christina BesslerII Concepta Margaret McManus ${ }^{I}$ \\ Ivo Pivato ${ }^{I}$ Sônia Nair Báo
}

\section{ABSTRACT}

Wharton's jelly is a source of mesenchymal stem cells (MSCs) that had not yet been tested for bovine embryo production by nuclear transfer (NT). Thus, the objective of this study was to isolate, characterize and test MSCs derived from Wharton's jelly for embryo and pregnancy production by NT in cattle. The umbilical cord was collected during calving and cells derived from Wharton's jelly (WJCs) were isolated by explant and cultured in Dulbecco's Modified Eagle Medium. Skin Fibroblasts (FB) were isolated after 6 months of life. Morphological analysis was performed by bright field and scanning electron microscopy (SEM) during cell culture. Phenotypic and genotypic characterization by flow cytometry, immunocytochemistry, RT-PCR and differentiation induction in cell lineages were performed for WJC. In the NT procedure, oocytes at the arrested metaphase II stage were enucleated using micromanipulators, fused with WJCs or FB and later activated artificially. SEM micrographs revealed that WJCs have variable shape under culture. Mesenchymal markers of $\mathrm{MSCs}\left(\mathrm{CD}_{29^{+}}, \mathrm{CD}_{73^{+}}, \mathrm{CD}^{2} 0^{+}\right.$and $\left.\mathrm{CD} 105^{+}\right)$were expressed in bovine-derived WJC cultures, as evidenced by flow cytometry, immunocytochemistry and RT-PCR. When induced, these cells differentiated into osteocytes, chondrocytes and adipocytes. After classification, the WJCs were used in NT. Blastocyst formation rate by NT with WJCs at day 7 was $25.80 \pm 0.03 \%$, similar to blatocyst rate with NT using skin fibroblasts $(19.00 \pm 0.07 \%)$. Pregnancies were obtained and showed that WJCs constitute a new cell type for use in animal cloning.

Key words: cloning, mesenchymal stem cell, umbilical cord.

\section{RESUMO}

A geleia de Wharton é uma fonte de células tronco mesenquimais (CTMs) que ainda não havia sido testada para a produção de embriões bovinos por transferência nuclear (TN). $O$ objetivo deste estudo foi isolar, caracterizar e testar as CTMs derivadas da geleia de Wharton para produção de embriões $e$ gestações por transferência nuclear em bovinos. O cordão umbilical foi coletado durante o nascimento e as células derivadas da geleia de Wharton (CGWS) foram isoladas por explante e cultivadas em Dulbecco's Modified Eagle Medium. Fibroblastos (FB) da pele foram isolados após 6 meses de vida. As análises morfológicas foram realizadas pelas microscopias de campo claro e eletrônica de varredura durante o cultivo celular. Caracterização fenotípica e genotípica por citometria de fluxo, imunocitoquímica, RT-PCR $e$ indução da diferenciação em linhagens celulares foi realizada com as CGWs. No procedimento de TN, ovócitos no estágio de metáfase II foram enucleados usando micromanipuladores, fusionados com CGWs ou FB e então ativados artificialmente. Micrografias de microscopia de varredura revelaram que CGWs tiveram forma variada sob cultivo. Os marcadores mesenquimais de CTMs $\left(C D 29^{+}, C D 73^{+}, C D 90^{+}\right.$and $\left.C D 105^{+}\right)$foram expressos em cultura de CGWs bovina, como evidenciado por citometria de fluxo, imunocitoquímica e RT-PCR. Quando induzidas, estas células diferenciaram-se em osteócitos, condrócitos e adipócitos. Após classificação, as CGWs foram utilizadas na TN. A taxa de formação de blastocistos por TN com CGWs no sétimo dia de

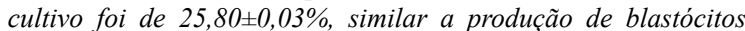
por TN com fibroblastos de pele $(19,00 \pm 0,07)$. Gestações foram obtidas e mostraram que CGWs constituem um novo tipo celular para ser usado na clonagem animal.

Palavras-chave: célula tronco mesenquimal, clonagem, cordão umbilical.

'Universidade de Brasília (UnB), Brasília, DF, Brasil.

"Laboratório de Reprodução Animal, Centro de Transferência de Tecnologia de Raças Zebuínas com Aptidão Leiteira (CTZL), Embrapa

Cerrados, 73310-970, Brasília, DF, Brasil. E-mail: carlos.martins@embrapa.br. "Corresponding author.

III Laboratório de Virologia e Cultivo Celular, Universidade Estadual Paulista (UNESP), Araçatuba, SP, Brasil. 


\section{INTRODUCTION}

The prevention of epigenetic errors has been suggested as a key to improve the success rate of animal cloning (WANG et al., 2011). Studies have shown significant differences between cell lines in the ability to produce embryonic development, and that the nuclei of cells which are less differentiated better support full embryo development, compared with those cells that are completely differentiated (HOCHEDLINGER \& JAENISCH, 2002). This makes the availability of cells whose nuclei are able to undergo epigenetic reprogramming and are easily obtainable an important pre requisite for nuclear transfer (NT). In this context, mesenchymal stem cells (MSCs) emerge as a promising source of cells to be used in NT.

MSCs are multipotent stem cells with well-defined characteristics and intrinsic capacity for self-regeneration and differentiation into functional cell types (BAKSH et al., 2004). Wharton's jelly is the connective tissue surrounding umbilical vessels (ABDULRAZZAK et al., 2010). Recently, CARDOSO et al. (2012) demonstrated that Wharton's Jelly is a source of mesenchymal multipotent cells in bovines. No studies were found where it had been used for the production of cloned animals.

With nuclear transplantation, the somatic nucleus carries the specific epigenetic modifications of its tissue type, which must be erased during nuclear reprogramming. Therefore, donor cells with less epigenetic modifications, such as lower levels of methylated DNA and/or higher levels of histone acetylation, may be reprogrammed more easily or more completely and, thus, give rise to improved cloning efficiency (ENRIGHT et al., 2003). KANG et al. (2001) affirmed that cloned blastocysts closely resembled donor cells in their overall genomic methylation status, which was very different from that of normal blastocysts produced in vitro or in vivo. Although no study has been done to epigenetic characterization of MSCs, further evaluations can be correlated to estimate the differentiation of this cell type, such as telomerase activity. The high activity of telomerase found in MSCs from bovine fetuses from Wharton's jelly (CARDOSO et al., 2012) allowed to state that this cell type is poorly differentiated.
Moreover, a great advantage in the use of umbilical cord cells is that this structure is of embryonic origin and can be collected after birth (CARLIN et al., 2006). Finally, the intermediate state between adult and embryonic stem cells make the fetal stem cells ideal candidates for reprogramming to pluripotent state (ABDULRAZZAK et al., 2010).

Thus, this study aimed to carry out isolation and characterization of cells from bovine Wharton's jelly retrieved from umbilical cord collected during calving and to test their ability to produce blastocysts and pregnancies by NT.

\section{MATERIALS AND METHODS}

Isolation and culture of bovine derived Wharton's jelly cells (WJC)

Parturition was induced in two pregnant cows using $10 \mathrm{~mL}$ intramuscular dexamethasone and $2 \mathrm{~mL}$ cloprostenol sodium. During assisted laboran approximately $5 \mathrm{~cm}$ fragment of sanguine vessels and umbilical cord jelly were collected. The umbilical cord fragment was separated into vessels and Wharton's jelly and small biopsies were obtained. Explants were cultured in Dulbecco's Modified Eagle Medium (DMEM, Invitrogen, USA) supplemented with $10 \%$ fetal bovine serum (FBS) (Gibco, Invitrogen, USA).

Scanning electron microscopy (SEM)

Evaluation of cells by SEM was performed as described previously by CUNHA et al. (2014). In short, WJC in eighth passage were washed in PBS and fixed with $2 \%$ glutaraldehyde and $2 \%$ paraformaldehyde in $0.1 \mathrm{M}$ sodium cacodylate buffer. The post fixing was performed with $1 \%$ osmium tetroxide and $0.8 \%$ potassium ferrocyanide. After the cells were dehydrated, it were submitted to critical point drying $\mathrm{CO}_{2}$ and metallization with gold. The analyses were performed in a scanning electron microscope Jeol 7001 (Tokyo, Japan).

In vitro multi-lineage differentiation assay

Adipogenic, ostegenic and chondrogenic differentiations were performed according to CARDOSO et al. (2012). For osteogenic differentiation STEMPRO $^{\circledR} \quad$ osteogenic differentiation 
medium (Invitrogen, USA) $(2 \mathrm{~mL} /$ well) was replaced every four days until 20 days of differentiation. The cells were fixed with $4 \%$ of paraformaldehyde (Sigma-Aldrich, USA), and calcium mineralization was assessed by Alizarin Red staining (Sigma-Aldrich, USA). For adipogenic differentiation, $2 \mathrm{~mL}$ of STEMPRO ${ }^{\circledR}$ adipogenic differentiation medium was replaced every $24 \mathrm{~h}$. After 15 days of differentiation, the cells were and stained with Oil Red solution. Induction of adipogenic differentiation was apparent by intracellular accumulation of lipid rich vacuoles that were stained with Oil Red. To induce chondrogenic differentiation, STEMPRO $^{\circledR}$ differentiation medium was supplemented with $100 \mu \mathrm{L}$ of chondrogenic inducer (Invitrogen, USA). Cells were kept under this condition for one week, replacing the medium every $24 \mathrm{~h}$. Cells were fixed and stained with Safranin O (Sigma-Aldrich, USA) to identify glycosaminoglycans.

Phenotypic and genotypic characterization

Immunocytochemistry, flow cytometry and reverse transcriptase polymerase chain reaction (RT-PCR) were performed according to CARDOSO et al. (2012).

Nuclear transfer and embryo transfer

Oocytes recovered from abattoir ovaries were selected for enucleation after $18 \mathrm{~h}$ of in vitro maturation (TCM 199 Earl's salt, supplemented with FBS $10 \%$, LH $12 \mu \mathrm{L} \mathrm{mL} \mathrm{mL}^{-1}$, FSH $10 \mu \mathrm{L} \mathrm{mL} \mathrm{m}^{-1}$, L-glutamine $10 \mu \mathrm{L} \mathrm{mL}^{-1}$ and

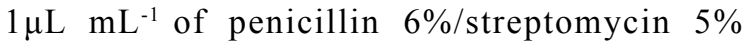
solution). Polar body and metaphase plate were removed with the aid of micromanipulators, and then only one Wharton jelly's cell or skin fibroblast between third and tenth passages was injected into the perivitelline space. Somatic cells-oocytes sets were placed in medium with $0.3 \mathrm{M}$ mannitol in a chamber with two electrodes connected to "Cell fusion and activation system Voltain EP-1". Reconstructed structures were manually aligned so that the contact surface between the membrane of the oocyte and the donor cell was parallel to the electrodes. Cell fusion was induced by two electrical pulses of $2.5 \mathrm{kV} \mathrm{cm}^{-1}$ for $65 \mu \mathrm{S}$, and activated with $5 \mu \mathrm{M}$ ionomycin for $5 \mathrm{~min}$ and $1.9 \mathrm{mM}$ of 6-dimethylaminopurine for $4 \mathrm{~h}$.
After activation, the embryos were cultured in synthetic ovidutal fluid. The parthenogenetic control was done to check the system of activation and culture.

Fifteen blastocysts were transferred non-surgically by transcervical way into 12 synchronic healthy recipient cows and pregnancy diagnosis by ultrasound was carried out at 35 days. Pregnancy development was monitored at 45 days and, so, every 30 days.

Statistical analysis

Experimental design was completely randomized, with four repetitions. Parameters analyzed were rates of cleavage and total blastocysts (D7 and D8). Means were compared using $t$ test $(\mathrm{P}<0.05)$. All analyses were performed using the statistical software Sigma Plot 13 (Systat Software, USA).

\section{RESULTS AND DISCUSSION}

This study constitutes the first report of embryo and pregnancy production by nuclear transfer using bovine MSCs from Wharton's jelly. These cells appear to be readily obtainable from a non invasive source that may represent a new cell type to be studied for bovine reproduction by NT.

Umbilical cord cells that were originated from extra-embryonic tissues have been classified as fetal MSCs in buffaloes (SINGH et al., 2013), canines (FILIOLI URANIO et al., 2011), equines (IACONO et al., 2012) and bovines (CARDOSO et al., 2012). Due to their origin, it was hypothesized that these cells can be more easily reprogrammed than skin fibroblasts and used in animal NT.

As an alternative source of MSCs, Wharton's jelly from the umbilical cord possesses desirable characteristics such as a large, rapidly available donor pool, non invasive and painless collection procedure, and an ethically noncontroversial source of MSCs. Moreover, MSCs derived from Wharton's jelly have extensive in vitro expansion capabilities and high multipotency, while also not induced teratomas (FONG et al., 2011). Another major advantage is that the umbilical cord is a fetal structure that can be collected after birth, with little risk to the 
animal and its cells can be used in re-cloning process, where a cloned fetus or embryo are disaggregated and used for a second round of nuclear transfer (ZAKHARTCHENKO et al., 1999). Due to these important characteristics, it was hypothesized that WJC collected from alive animals could be an important source of donor nuclei cells to improve the production of cloned cattle.

Wharton's jelly cells (WJC) in culture presented a high potential for adherence and multiplication. In the early culture stages, cells presented a fibroblastoid shape observed under an inverted bright field microscope. With the advancement of the culture (P8) the WJC showed no definite form (Figure 1). Scanning electron microscopy analysis reported variation in cell shape between the adherent and transition suspension-adherence phases. SEM images demonstrated that WJC assumed a spherical shape without villosities in the transition suspension-adherence phase (Figure 1). Our data corroborated the findings of CUNHA et al. (2014).

The minimum criteria to define MSCs are your ability to adhere to plastic when kept under cultivation conditions, and present surface antigen expression patterns including CD29, CD44 (WAGNER et al., 2005), CD73, CD90 and CD105 (DE MATTOS CARVALHO et al., 2009); furthermore, no one presented expression of the hematopoietic lineage markers (WAGNER et al., 2005). Also, they had ability to differentiate into osteoblasts, chondroblasts and adipocytes in vitro (PITTENGER et al., 1999). Expression patterns found by immunophenotyping WJC revealed that more than $80 \%$ of isolated cells were positive for CD29, CD73, CD90 and CD105 MSC markers and negative for CD34, CD44 and CD45 (Figure 2). Similarly, the immunocytochemistry corroborated the results obtained in flow cytometry, as observed in figure 2, as well as RT-PCR (Figure 2). Cells fixed and stained with Alizarin Red demonstrated matrix calcification indicating osteogenic differentiation. For chondrogenic differentiation, after Safran in $\mathrm{O}$ staining, the presence of glycosaminoglycans was observed as red deposits in the cells. Finally, adipogenic differentiation was shown by lipid vacuoles inside the cells, stained positively using Oil Red (Figure 1).
Results of cleavage and embryo production by NT using WJC and skin fibroblasts as nuclear donors are seen in table 1 . WJC presented fusion rate higher than skin fibroblast $(\mathrm{P}<0.05)$. This event maybe due to increased size of the WJC, which enlarged the contact area between the zona pellucida and plasm membrane, and consequently helped the fusion process. Despite the cleavage has been superior in nuclear transfer using fibroblasts, the blastocyst rate was similar between WJC and skin fibroblast donors in NT. At 35 days, two recipient cows were confirmed pregnant by embryos reconstructed with WJC. One recipient cow presented a double pregnancy (Table 1).

KATO et al. (2004) and COLLEONI et al. (2005) achieved $39 \%$ and 63.7 blastocysts, respectively, by using bone marrow derived MSCs as nuclear donors. Embryo production was higher than that obtained in the current work $(25.5 \% \pm 0.03)$. Since the rate of cells positive for surface markers of MSCs was bigger than $80 \%$, it is technically impossible to determine precisely whether all the cells used during the NT procedure were MSCs and this factor may have reduced blastocyst production rate. Furthermore, the aforementioned studies have not reported the percentage of MSCs obtained from the primary culture of bone marrow cells, which may be higher than that obtained from Wharton's jelly, explaining the decrease in blastocysts production rate.

Also in the report of KATO et al. (2004), the birth of a living and healthy calf from NT with bone marrow MSCs was described. Here, it was demonstrated a $20 \%$ pregnancy rate using MSCs from Wharton's jelly. Observing both results, of pregnancy and birth, it can be affirmed that MSCs are good candidates for bovine cloning.

In conclusion, we have demonstrated be possible to obtain embryos and pregnancies with mesenchymal stem cells from Wharton's jelly of the umbilical cord of live animals; so, these cells have developmental totipotency after NT. We proved further that the collection of this type of tissue proved to be simple and noninvasive, emerging as a new source of mesenchymal stem cells in live animals to be used in reproductive biotechnologies, including obtaining clones for NT. 


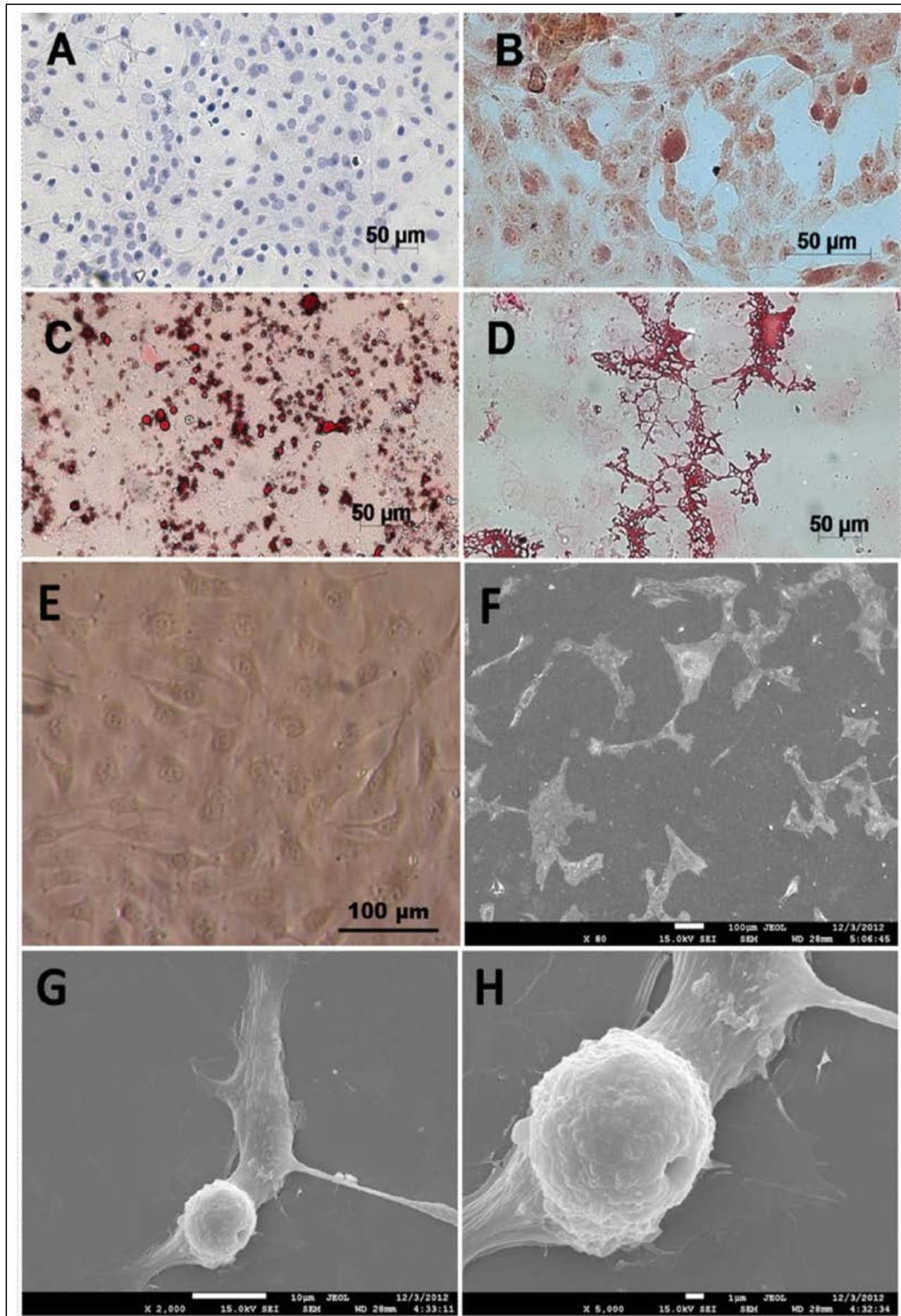

Figure 1- Differentiation in cell lineages (A-D) and morphologic characterization (E-H) of mesenchymal stem cells derived from bovine Wharton's jelly in bright light microscopy (E) and scanning electron micrographs (F-H). Control (A); differentiation into chondrocytes as confirmed by Safranin O staining, revealing glycosaminoglycans (B); differentiation into adipocytes as confirmed by staining with Oil red, highlighting lipid deposits in red (C); differentiation into osteocytes with calcium deposits was confirmed by staining with Alizarin (D). Cells presented fibroblastoid form in the early stages of culture (E) and no definite form in the eighth passage (F). During the transition phase between suspension and cell adhesion, cells presented a spherical shape, irregularities and absence of villosities on the surface ( $\mathrm{G}$ and $\mathrm{H})$. 


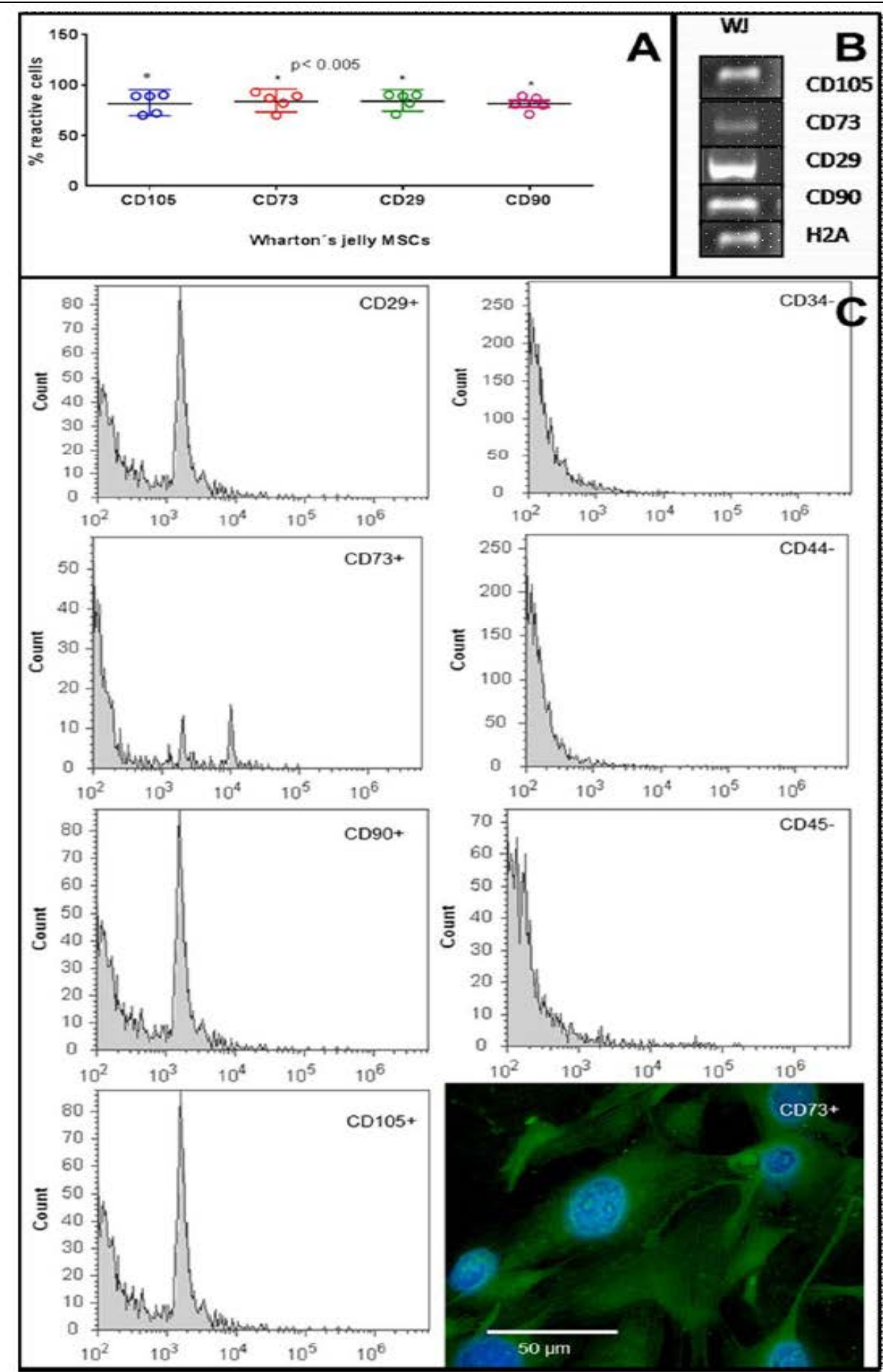

Figure 2 - A) Reactive cell percentage for each surface marker obtained by transformation of the results of Acoustic Flow Cytometer and Immunostaining into geometric mean of logarithm of 5 repetitions with 95\% confidence interval. "mean statistical different $(\mathrm{P}<0.005)$. B) A typical profile of mesenchymal stem cells was exhibited by bovine-derived Wharton's jelly (WJ) cells using reverse transcription-polymerase chain reaction. (H2A - Histone 2A). C) Histograms of flow cytometric analyses of surface marker expression in bovine-derived Wharton's jelly cells. Cells presented the surface antigen required for their characterization as mesenchymal stem cells. Data was processed by Attune ${ }^{\mathrm{TM}}$ acoustic focusing cytometer and excluded auto fluorescence as a global compensation tool $\left(\leq 10^{3}\right)$. Y-axis represents log scale. The immunocytochemical micrograph illustrates the positive cell culture for CD73 marker. 
Table 1 - Rates of fusion, cleavage, embryos and pregnancies obtained by nuclear transfer using Wharton's jelly cells.

\begin{tabular}{llllll}
\hline Treatments & Maturation (\%) & Fusion (\%) & Cleavage (\%) & Blastocyst total (\%) & Pregnancies D35 (\%) \\
\hline${ }^{*}$ WJ & $72.4 \pm 8.1^{\mathrm{a}}$ & $69.4 \pm 10.2^{\mathrm{a}}$ & $40.8 \pm 0.0^{\mathrm{b}}$ & $25.5 \pm 0.0^{\mathrm{b}}$ & $20.0(3 / 15)$ \\
${ }^{* *}$ FB & $53.0 \pm 0.0^{\mathrm{b}}$ & $44.8 \pm 0.0^{\mathrm{b}}$ & $70.6 \pm 0.1^{\mathrm{a}}$ & $19.0 \pm 0.0^{\mathrm{b}}$ & \\
${ }^{* * * *}$ PNG & & & $78.9 \pm 9.8^{\mathrm{a}}$ & $42.9 \pm 15.9^{\mathrm{a}}$ & \\
\hline
\end{tabular}

${ }^{\mathrm{a}, \mathrm{b}}$ In the columns, different letters $(\mathrm{a}-\mathrm{b})$ represent significative difference $(\mathrm{P}<0.05)$.

${ }^{*}$ WJ: Wharton's jelly cells.

*FB: Fibroblasts.

*** PNG: Parthenogenetic control.

\section{ACKNOWLEDGEMENTS}

The authors thank Embrapa (MP1 Project 01.13.06.001.06.02.004), Coordenação de Aperfeiçoamento de Pessoal de Nível Superior (CAPES); Fundação de Apoio à Pesquisa do Distrito Federal - PRONEX/FAPDF (193.000.048/2009); Conselho Nacional de Desenvolvimento Científico e Tecnológico (CNPq) (30116/2009-1); and Financiadora de Estudos e Projetos - Finep (CTInfra-01/2005) for financial support.

\section{BIOETHICS AND BIOSSECURITY COMMITTEE APPROVAL}

All the procedures of experimentation were approved by the Ethics Committee in Animal Use at the Universidade de Brasília (protocol number 151101/2013).

\section{REFERENCES}

ABDULRAZZAK, $H$. et al. Biological characteristics of stem cells from foetal, cord blood and extraembryonic tissues. Journal of The Royal Society Interface, v.7, p.S689-706, 2010. Available from: $<$ http://rsif.royalsocietypublishing.org/content/7/Suppl_6/S689. long $>$. Accessed: July 21, 2015. doi: 10.1098/rsif.2010.0347.focus.

BAKSH, D. et al. Adult mesenchymal stem cells: characterization, differentiation, and application in cell and gene therapy. Journal of Cellular and Molecular Medicine, v.8, p.301316, 2004. Available from: <http://onlinelibrary.wiley.com/ doi/10.1111/j.1582-4934.2004.tb00320.x/abstract;jsessionid=11D 01554E9D40BCD8F7293F7FD7F2D4D.f04t01>. Accessed: July 21, 2015. doi: 10.1111/j.1582-4934.2004.tb00320.x.

CARDOSO, T.C. et al. Isolation and characterization of Wharton's jelly-derived multipotent mesenchymal stromal cells obtained from bovine umbilical cord and maintained in a defined serum-free threedimensional system. BMC Biotechnology, v.12, p.1-11, 2012 Available from: <http://www.biomedcentral.com/1472-6750/12/18>. Accessed: July 22, 2015. doi: 10.1186/1472-6750-12-18.

CARLIN, R. et al. Expression of early transcription factors Oct-4, Sox-2 and Nanog by porcine umbilical cord (PUC) matrix cells. Reproductive Biology and Endocrinology, v.4, p.1-13, 2006. Available from: <http://www.rbej.com/content/pdf/1477-7827-48.pdf>. Accessed: Nov. 27, 2015. doi: 10.1186/1477-7827-4-8.

COLLEONI, S. et al. Establishment, differentiation, electroporation, viral transduction, and nuclear transfer of bovine and porcine mesenchymal stem cells. Cloning and Stem Cells, v.7, n.3, p.154-166, 2005. Available from: <http://online.liebertpub. com/doi/abs/10.1089/clo.2005.7.154>. Accessed: Nov. 27, 2015. doi: 10.1089/clo.2005.7.154.

CUNHA, E.R. et al. Effects of prolonged in vitro culture and cryopreservation on viability, DNA fragmentation, chromosome stability and ultrastructure of bovine cells from amniotic fluid and umbilical cord. Reproduction in Domestic Animals, v.49, p.806-812, 2014. Available from: <http://onlinelibrary.wiley. com/doi/10.1111/rda.12372/abstract;jsessionid=046109A3E7400 262202BDF58BFEF833E.f04t03>. Accessed: July 22, 2015. doi: $10.1111 /$ rda. 12372 .

DE MATTOS CARVALHO, A. et al. Isolation and immunophenotypic characterization of mesenchymal stem cells derived from equine species adipose tissue. Veterinary Immunology and Immunopathology, v.132, p.303-306, 2009. Available from: <http://www.sciencedirect.com/science/article/pii/ S0165242709002141>. Accessed: July 22, 2015. doi: 10.1016/j. vetimm.2009.06.014.

ENRIGHT, B.P. et al. Epigenetic characteristics of bovine donor cells for nuclear transfer: levels of histone acetylation. Biology of Reproduction, v.69, p.1525-1530, 2003. Available from: <http:// www.biolreprod.org/content/69/5/1525.full.pdf + html $>$. Accessed: Nov. 27, 2015. doi: 10.1095/biolreprod.103.019950.

FILIOLI URANIO, M. et al. Isolation, proliferation, cytogenetic, and molecular characterization and in vitro differentiation potency of canine stem cells from foetal adnexa: a comparative study of amniotic fluid, amnion, and umbilical cord matrix. Molecular Reproduction and Development, v.78, p.361-373, 2011. Available from: <http:// onlinelibrary.wiley.com/doi/10.1002/mrd.21311/abstract>. Accessed: July 22, 2015.doi: 10.1002/mrd.21311.

FONG, C.Y. et al. Human Wharton's jelly stem cells have unique transcriptome profiles compared to human embryonic stem cells and other mesenchymal stem cells. Stem Cell Reviews and Reports, v.7, p.1-16, 2011. Available from: <http://link.springer. com/article/10.1007\%2Fs12015-010-9166-x>. Accessed: July 22, 2015. doi: 10.1007/s12015-010-9166-X.

HOCHEDLINGER, L.; JAENISCH, R. Monoclonal mice generated by nuclear transfer from mature $\mathrm{B}$ and $\mathrm{T}$ donor cells. Nature, v.415, p.1035-1038, 2002. Available from: <http://www. nature.com/nature/journal/v415/n6875/full/nature 718.html $>$. Accessed: Nov. 27, 2015. doi: 10.1038/nature718.

IACONO, E. et al. Isolation, characterization and differentiation of mesenchymal stem cells from amniotic fluid, umbilical cord blood 
and Wharton's jelly in the horse. Reproduction, v.143, p.455468, 2012. Available from: <http://www.reproduction-online.org/ content/143/4/455.long>. Accessed: July 22, 2015. doi: 10.1530/ REP-10-0408.

KANG, Y-K. et al. Aberrant methylation of donor genome in cloned bovine embryos. Nature Genetics, v.28, p.173-177, 2011. Available from: <http://www.nature.com/ng/journal/v28/n2/full/ ng0601_173.html>. Accessed: Nov. 27, 2015. doi: 10.1038/88903.

KATO, Y. et al. Nuclear transfer of adult bone marrow mesenchymal stem cells: developmental totipotency of tissue-specific stem cells from an adult mammal. Biology of Reproduction, v.70, p.415-418, 2004. Available from: <http://www.biolreprod.org/ content/70/2/415.full.pdf + html $>$. Accessed: Nov. 27, 2015. doi:10.1095/biolreprod.103.020271.

PITTENGER, M.F. et al. Multilineage potential of adult human mesenchymal stem cells. Science, v.284, p.143-147, 1999. Available from: <http://www.sciencemag.org/content/284/5411/143.long>. Accessed: July 22, 2015. doi: 10.1126/science.284.5411.143.

SINGH, J. et al. Cultured buffalo umbilical cord matrix cells exhibit characteristics of multipotent mesenchymal stem cells. In
Vitro Cellular \& Developmental Biology- Animal, v.49, p.408416, 2013. Available from: <http://link.springer.com/article/10.100 7\%2Fs11626-013-9617-1>. Accessed: July 22, 2015. doi: 10.1007/ s11626-013-9617-1.

ZAKHARTCHENKO, V. et al. Effects of serum starvation and re-cloning on the efficiency of nuclear transfer using bovine fetal fibroblasts. Journal of Reproduction and Fertility, v.115, p.325331, 1999. Available from: <http://www.reproduction-online.org/ content/115/2/325.full.pdf + html $>$. Accessed: Nov. 27, 2015.

WAGNER, W. et al. Comparative characteristics of mesenchymal stem cells from human bone marrow, adipose tissue, and umbilical cord blood. Experimental Hematology, v.33, p.1402-1416, 2005. Available from: <http://www.exphem.org/article/S0301472X(05)00364-4/abstract>. Accessed: July 22, 2015. doi: 10.1016/j.exphem.2005.07.003.

WANG, Y.S. et al. Production of cloned calves by combination treatment of both donor cells and early cloned embryos with 5-aza2/-deoxycytidine and trichostatin A. Theriogenology, v.75, p.819825, 2011. Available from: <http://www.theriojournal.com/article/ S0093-691X(10)00550-9/abstract>. Accessed: July 22, 2015. doi: 10.1016/j.theriogenology.2010.10.022. 